DESSEFFWY TIBOR

\title{
Levélféle az ökocídium lovasához
}

\section{Szerzői információ:}

O D e s s e wf $\mathrm{T}$ ibor

Szociológus, az ELTE Társadalomtudományi karának habilitált docense. Az ELTE Információs Társadalom- és Hálózatkutató Központ (ITHAKA) alapítója és vezetôje. A World Internet Project magyarországi kutatásának tudományos vezetôje. Fontosabb mûvei: Internet.hu (szerk. Z. Karvalics Lászlóval, Aula, 2003), A kocka el van veszve (Aula , 2002) Melan-Cola (Helikon 2002) Iskola a hegyoldalban (Új Mandátum, 1999), Kedélyes labirintus (Új Mandátum, 1997).

\section{Így hivatkozzon erre a cikkre:}

Desseffwy Tibor. „Levélféle az ökocídium lovasához”.

Információs Társadalom IV, 3-4. szám (2004): 47-50.

- https://dx.doi.org/10.22503/inftars.IV.2004.3-4.7

A folyóiratban közölt müvek

a Creative Commons Nevezd meg! - Ne add el! - Így add tovább! 4.0

Nemzetközi Licenc feltételeinek megfelelöen használhatók. 
Dess ewffy Tibor

Levélféle az ökocídium lovasához

Is this the real life?

Is this just fantasy?

Caught in a landslide,

No escape from reality

Open your eyes, Look up to the skies and see, I'm just a poor boy, I need no sympathy,

Because I'm easy come, easy go, Little high, little low, Any way the wind blows doesn't really matter to me, to me.....

Bohemian rapsody

\section{Kedves Miklós,}

Látom, értem, hogy írásod valóban húsbavágó, brutálisan fontos kérdéseket feszeget. Ezzel együtt úgy érzem, az egész okfejtés azokra a német balszélsôkre emlékeztet, akik már annyira koncentráltan trükköznek, hogy észre sem veszik, hogy kifutottak a pályáról és a büfét is elhagyva már az öltözőkön túl cselezgetnek.

Mint barátod szeretném jelezni, hogy szerintem rossz úton jársz - vagy legalábbis, ami biztonsággal mondató, nem azon az úton, amin én. Ami ennél nagyobb baj, hiszen ezt lehetne akár filozófiai, ízlésbeli különbségnek is felfogni, néhány helyen annyira megbicsaklik az érvelés, hogy azt reflexív értelemmel nehéz követni.

Sok minden kavarog ebben az írásban, noha a mediatizáció és az ökológiai katasztrófa viszonyának tisztázását ígéri, amelyről persze magad is írod, hogy nem oksági, a mediatizált világ inkább a segítô kontextust jelenti, ahol az ökocidium végbemegy - bár aztán mintha ennek épp az ellenkezóje mellett érvelnél.

Tematikusan három nagyobb részre lehet bontani az ellenvetéseket.

Elôrebocsátom, nem vagyok ökoterrorista-elhárító, én is jobban szeretem a friss levegót, mint a büdöset, a tiszta vizet, mint a ciánosat. Tisztában vagyok a Beck utáni fordulattal is a szociológiában, hogy a zöld gondolat - mint hajdan az olajárrobbanás - begyưrûzzött a társadalomtudományokba. De:

1. Egyrészt az írás ki nem mondottan a modernitás kritikai megközelítéséből indul ki. Ez nagyon fontos kérdés, én is sokáig küszködtem vele és azt hiszem, minden felelôssen gondolkodó embernek itt le kell tennie a garast. Ma sokszor idézgetik nevetgélve Keynest: hosszú távon mindannyian halottak leszünk. Kevesebben emlékeznek arra, hogy ezt Schumpeterrel folytatott vitájában mondta, reagálva az osztrák közgazdász hosszú távú szemléletére, mivel Schumpeter a kapitalizmust védve folyton és helyesen - azt kérdezte, nem jobb-e ma a világ, mint a 19. században? Nem jobbe a posztindusztriális kapitalizmus, mint a manchasteri? A nagy Peter L. Berger erról azt mondja: a boldogság mérhetetlen (lényegében, mert viszonyítási keretek kérdése), de tisztelnünk kell annyira az életet, hogy elfogadjuk az emberi szenvedés mérőszámait: a csecsemőhalandósági arányt, meg a várható élettartamot: ezek az elmúlt évszázadban a fejlett világban elképesztô mértékben javultak. (Bár a népességrobbanásnak semmi köze a posztindusztrializmushoz, szemben azzal, amit írsz, hiszen ez, 
mármint a népesedési robbanás tipikus indusztrializációs jelenség). De ebból a bergeri tételből követezik, hogy az emberek - más szóhasználatban: "tömegek" - számára életminôség-javulást hozott a (késố) modernitás. Ugye jobban szeretnénk, ha Magyarország Hollandia vagy Finnország felé menne, mint ha Uganda vagy Kenya fejlödési pályáját követné? Vagy médiaszempontból, ugye jobb a BBC, mint a szudáni kettes csatorna?

Tudom, hogy komoly érvek szólnak a modernitás negatív értékelése mellett is: a fasizmus, a kommunizmus és most a környezetrombolás valós szörnyúségei. Egy kategorizációs hibát látok itt: attól, hogy a galóca is gomba, még nem kell elvetni a csiperkét, betiltani a kalaposokat. Vagyis a modernitás sötét kifutású pályái miatt nem szabad megfeledkezni a „fényesebb ösvényekről”, arról a fejlődési pályáról, amely a liberális demokráciákhoz és a jóléti államokhoz vezetett.

Vagyis lehet a divatos Benjamin-idézettel minôsíteni a borzalmakban kétségkívül nem szúkölködő (késô) modernitást, vagy az elmúlt kétszáz évet, de ez szerintem leegyszerűsítő, mert emellett ott van a „bőségszaru”, „a proletár reneszánsz”, a jólét és az életminóség-növekedés. Ez nem jelenti azt, hogy nincs tere a kritikának: természetesen rengeteg ocsmány és helytelen dolog történik ebben a rendszerben, de a rendszert magát én sem a szociológiai realitások szintjén, sem a vágyak és álmok szintjén nem tudom elvetni, mert nem látok életképes alternatívákat. Látok viszont ezen a struktúrán belül számos különbséget és azt a feladatot, hogy az értékeinknek megfelelőbb (európai, skandináv) modell felé közelítsük a mi posztkommunista világunkat. Ebben az amúgy mérhetetlenül nagy feladatban nem segítenek az apokaliptikus, az egész rendszer legitimitását elutasító víziók.

2. Mediatizáció. Az előbbi egyoldalúságból fakad a mediatizáció torz értékelése is. Hiszen ha a modernitás csak borzalmakat hozott, akkor az emberek, a „tömegek”, akik ezt választják, nyilván valamiféle agymosott, tudathasadt, konzumer regresszióban kell, hogy létezzenek.

Megint csak persze sok igazság van abban, amit írsz; idômérleg, élmény-autenticitás, stb. De nagyon kiegyensúlyozatlan, egyoldalú az értékelés. Éppenséggel Benjamin is tiltakozna, hiszen miközben az aura elveszítéséről beszél, ő pontosan látja, hogy a sokszorosítás demokratizál is, mivel szélesebb körben teszi elérhetôvé a műalkotásokat. Mint ezt te is nagyon jól tudod, épp benjamini alapokon szoktak érvelni az „audience studies”-ban: nem eszik olyan forrón a kását, attól hogy sok órányi tévét nézünk, még nem válunk a músorok lenyomatává. Nem azt állítom, hogy nem nagyon fontos a mediatizált tudáskonstrukció (mivel majd tíz éve erról írok, ez elég vicces is lenne az én klaviaturámból), hanem azt, hogy ez a hatás megint csak összetettebb, ha tetszik, humanizáltabb, mint te írod. Azért meglepő ez a redukcionizmus, mert épp azok az új diszciplinák (cultural studies, media studies, audience studies) ismétlik ezeket a tételeket már-már unalomig, amiket te nagyon jól ismersz és tanítasz már régóta.

Csak egyetlen friss példa a politikai kihatásokról: érdemes megnézni a kiváló Pippa Norrist, akinél még a közbeszéd tabloidizációja is pozitív demokratikus értelmet kap, mivel nem kinyilatkoztat, hanem elgondolkoztatóan mér és elemez.

A téves alapállás mellett sok zavaró pontatlanság is van itt: azt állítod, hogy a környezet „alulreprezentált” a médiában - ez kérdéses, illetve mihez képest? Egy si- 
vatagi nomádnak nyilván közvetlenebb a kapcsolata a természettel, de az elmúlt harminc év magyar tapasztalatai szerintem azt mutatják, hogy sokkal több környezeti (és környezetvédelmi) téma tud megjelenni a médiában ma, mint akkor, amikor ez az egész diskurzus még nem is létezett.

- A Greenpeace-t nem említed itt, pedig eklatáns példa a médialogika környezetvédelmi felhasználására.

- Ha el is fogadjuk, hogy a média kizárólag a fogyasztást szolgálja ki és generálja, ami részben persze nyilván igaz, itt is a totalizáló beszédmód a probléma. A fogyasztás emberi- kommunikációs jelentésekkel teli oldalairól ajánlom figyelmedbe mondjuk Daniel Millert, vagy bárkit, aki ezzel nem a kritikai értelmiség előítéletes attitûdjével, hanem empirikusan, a megértés szándékával, emberközelből foglakozik. Vagy a saját élettapasztalataidat: amikor a gyerekeidnek judo-ruhát veszel, a feleségedtôl fésût kapsz, akkor érzelmeket (is) kommunikáltok, nem pedig elidegenedett véglényekként konzum-mákonyba ájultok - szerintem.

- Ami az információs társadalom kontextusában különösen fájdalmas: a homogenizált médiafogalomban egybemosod a tévét (one to many) az Internettel (many to many) - ebbe most nem is akarok belemeni, mert túl sokat lehetne írni róla, és a különbség neked különösen nyilvánvaló lenne, ha belegondoltál volna.

De ami a lényeg, szerintem, hogy itt is van egy mögöttes, nem reflektált filozófiai alapvetés: a face to face, verbális kommunikació a „valódi”, az „igazi”. Ezzel szemben én úgy látom, hogy ez is egy történelmi szakaszra volt jellemzô: volt egy beszéd elő́tti szakasz, most egy másik szakasz van, és ennek is megvannak a maga szabályai. Ha nem a világ végét hirdetjük, hanem ennek a sajátosságait nézzük, akkor nincs olyan nagyon nagy baj. Más, mint az előző volt, de hol van az megírva, hogy a 18. századi szalonok kommunikációs patternjei lennének univerzálisak??

3. Lényegében ez a helyzet az ökológiával is. Mint írod, volt már öt katasztrófa az elmúlt sok ezer évben és most egy hatodik közeleg. Ha cinikus akarnék lenni, mondhatnám, mi a probléma - ennyi, one shot jár a homo sapiensnek is, de nem akarok cinikus lenni, csak felvetem, hogy a Föld, Gaia élölény, vál tozik, alakul: az emberrel és az ember nélkül is eltûnnek és megjelennek fajok. Tehát nem feltétlenül ontológiai tragédia, ha eltûnnek a bazsarózsák. Más kérdés, hogy az embernek természetesen törekednie kell arra, hogy a saját környezetét élhetővé tegye, a bioegyensúlyt ne borítsa fel.

De észre kell venni, hogy az indusztriális-posztindusztriális korszakváltás, amiben élünk, ebből a szempontból mindenképp pozitív: lásd pl. Hamburgban a korábban 200 évig mérgezett, de mára újra úszhatóvá tett Elbát, vagy Pittsburgh-ot, a hajdani acélvárost, ami ma tiszta levegőjû és élhető.

Ebből megint nem következik, hogy az amerikai pazarlást kell támogatni, azokat az autókat, amelyek 30 liter benzint fogyasztanak százon, de Európa ebből a szempontból is más úton jár, vannak lényegi különbségek - igaz, ezek megjelenítése túlmegy egy ilyen tézis-paper keretein... 
Végül a stílusról - nines azzal semmi baj, ha valaki Karácsony Gábor- és Lányivagy éppen Freddy Mercury-idézeteket használ, azonban azt látni kell, hogy ốk mûvészek, akik esszéikben saját érzéseiket, félelmeiket és szorongásokat vetítik ki, amely érzésekben nyilván mi sem szúkölködünk. Azonban azt hiszem, a szociológiai gondolkodás, a millsi „képzelet” nehezen megragadható lényege az, hogy nem csak kilövelljük a világfájdalmunkat, hanem reflektáltan megnézzük innen is, onnan is az egyes állítások, feltételezések érvényességét. Ez az elv ebben az írásban néha elfelejtôdik, ami nem probléma a mûvészet esetében, de igenis nagy baj egy önmagát szociológai szövegként definiáló dolgozat esetében. 